\title{
The Complexities of Neo-Liberalism in Post-Apartheid South Africa
}

\author{
N.B. Breakfast
}

Stellenbosch University, South Africa

\begin{abstract}
This article examines the contradictions and complexities of the model of development pursuit by the African National Congress (ANC) government in post-apartheid- South Africa. The article intends to shed some light on the current economic trajectory of South Africa by arguing that although there are some elements of neo-liberalism in government policies, namely: privatisation of services, inflation targeting and Public-Private Partnerships. However, the expansion of the size and the role of the South African state, are anti-neo-liberal. This is a qualitative literature assessment article; because it is based on desktop research. This article is located within the Marxism and Leninism tradition as a standpoint theory. This ontological approach is chosen owing to its meticulousness in teasing out the complexities of the capitalist mode of production. The aim of this article is to lay bare the different aspects of the mixedbag approach of development employed by the South African government by asserting that is not simply neo-liberal in nature though to some extent it is inspired by market-friendly policies. This also indicates the gaps in the discourse with regard to the implementation of neo-liberalism in South Africa. This article contributes to the South African political economy debate by arguing that neo-liberalism has contradictions and complexities; it is not simplistic and straightforward.
\end{abstract}

Keywords: Neo-liberalism, privatisation of services, market-friendly policies.

\section{INTRODUCTION}

Neo-liberalism is a mainstream model of development within development theory and practice. However, it must be noted that a number of scholars and political leaders have been asking for alternative models of development; because of the contradictions and the complexities of neo-liberalism. In practice, neoliberalism allocates state resource to political wellconnected people as opposed to the majority (Harvey, 2005:21).

The neo-liberal model of development advocates for deregulation of the economy, the rolling-back of the state, low taxes for the ruling class and the reduction of government expenditure. Neo-liberalism has been promoted across the globe since its implementation in South American countries during the 1970s. The first economic experiment was executed by the 'Chicago Boys', owing to the influence of neo-classical economics in Chile during the Pinochet government. Market-friendly economic policies are not a solid foundation to promote development for the majority of people in society (Saul, 2005:190-194). Neoliberalism promotes income and social inequality which poses a series danger to consolidation of democracy (Hibell, 2008:1).

Market fundamentalism creates a scope for unregulated personal accumulation of the economic and political elite and leads to inequalities as well as

*Address correspondence to this author at the Stellenbosch University, South Africa; Tel: (022) 702 3195; Fax: 022702 3050;

E-mail: nb.breakfast@ma2.sun.ac.za the erosion of the culture of democracy. The consequences of unfettered neo-liberalisation produces a threat to democracy; owing to maximization of profit and the creation of structural economic problems. Paradoxically, the idea of democracy is meant to promote both procedural and substantive equality for all and sundry. Democracy also means that the culture of human rights will be respected, in particular the socio-economic rights of the downtrodden (Breakfast, 2013:25-26, 2014-74).

The 2008 recession has affected the working class world-wide, and South Africa has also witnessed a number of social protests nationwide by people complaining about poverty, unemployment, housing and the increasing food prices. The state capture has also created a platform for personal accumulation for both the political and business elite and escalated the magnitude of social unrest in South Africa; owing to the failure of the ruling party to promote development for the majority.

It is widely accepted uncritically both in the domain of social sciences and public discourse that the application of neo-liberalism is South Africa has occurred in a post-apartheid social order as a result of the introduction of the Growth Employment and Redistribution (GEAR) policy. Although GEAR as a macro-economic policy was an expression of neoliberalism, market fundamentalism has always been embedded in the structure of the economy of South Africa. For instance, in the late 1980s the apartheid government privatised key state institutions, namely: Transnet, a small scale privatisation of Iscor and Safmarine. Against this background, this article 
examines the application of neo-liberalism in South Africa. Secondly, this article argues that neoliberalism is not only imposed by multi-lateral institutions such as the International Monetary Fund and the World Bank via the structural adjustment programmes. Nonetheless, neo-liberalism is also created by local political and business elites at local government level through privatisation of services.

There is a strong view among the socialists in South Africa that the African National Congress (ANC) is pursuing a neo-liberal agenda. On the contrary, the expansion of the size and the role of the South African state, are not inspired by neo-liberalism. The ANC government in 2010 adopted a state led policy such as the 'New Growth Path' which supports the idea of a developmental state as opposed to the populist view that South Africa is just simply implementing businessfriendly policies. Moreover, the National Development Plan (2011:38) supports the notion of creating a capable South African state. This is an anti-thesis of neo-liberalism; precisely because it is a state led approach which is in line with the conception of having a developmental state in future in South Africa. However, this does not mean that there are no business-friendly policies in South Africa, such as outsourcing of services, Broad-Based Black Economic Empowerment (BBBEE), (though it also has an element of state interventionism by regulating the workings of the market-forces). This implies that neoliberalism as a model of development is not simplistic and straight forward. Conversely, it has complexities and contradictions at play. David Byrne (1998) follows the line of thinking when he argues that social phenomena are complex as opposed to be simplistic and should be problematised as such. Lastly and most importantly, this article provides a closer examination of the development policy trajectory of the ANC government imbued with both neo-liberal and anti-neoliberal tendencies since 1994. The following section lays out the theoretical framework of this article.

\section{THEORETICAL FRAMEWORK}

This article is embedded within the Marxism and Leninism tradition as a standpoint theory. This ontological approach is chosen owing to its meticulousness in analysing the complexities of the capitalist mode of production. Marxism and Leninism is an integration of the ideas of Karl Marx, Friedrich Engels and Vladimir Lenin. Equally, it must be noted that Marxism and Leninism is not limited to a situational analysis of one country or continent. It cuts across all continents in the world. What is central to the capitalist mode of production is maximization of profit and capital accumulation (Marx, 1867). This occurs through surplus value; whereby the working class sells its labour power for long hours in exchange for income nonetheless the capitalist class appropriate the profit and exploits the proletariat (Marx, 1867). Engels and Marx (1848:1) saw the history of human beings as a class struggle. Both theoreticians used historical materialism to trace the origins of capitalism by linking it to feudalism. Capitalism was born out of industrialisation in Europe and expanded to other parts of the world. Vladimir Lenin (1916:1) in his writing: Imperialism, the highest stage of capitalism, points out that imperialism came to the fore as a result of the development of capitalism.

The capitalist system has always been characterized by class contradictions. These class contradictions reproduce an unequal relationship between the working class and ruling class owning to the structure of the economy which leads to the misery of the material conditions of the proletariat. Social relationships in a capitalist mode of production are determined by those who owns the means of production (Engles and Marx, 1848, Marx, 1867). Lenin held a view that capitalism based on its principle of fair competition is contradictory in nature. On the one hand, it embraces fair competition between businesses in all countries through imperialism. On the other hand, capitalism is allowing monopolization of the markets by multinational co-operation (Lenin, 1916:1). In the early 1900 s or twentieth century, an argument broke out within the Marxists circles with regard to party, class and revolution. In the main, the argument was a thesis of Vladimir Lenin and an anti-thesis of Rosa Luxemburg on strategies and tactics of the working class. These two intellectuals made a substantive contribution to the body of knowledge of the left.

On the one hand, Luxemburg (2010) argued that a mass movement is not the only vehicle towards socialism; simply because some struggles are spontaneous and that the working class needs to engage in mass strikes. She also argued that there is nothing wrong in advocating for reforms as a tactic not as a strategy for socialism. Meaning that reforms are not a destination. They are just a mechanism to deal with the immediate material conditions of the working class (Luxemburg, 2010). On the other hand, Lenin propagated the notion of a vanguard. This means that the working class cannot work/function outside the party. The role of the party is to push or champion the 
program of socialism. The party has a responsibility to instil political and class consciousness. Lenin held a view that the working class should not only wage an economic war, however it needs to work side by side with the labour movement (Lenin, 1901).

These ideas of both Lenin and Luxemburg on class struggle remain the philosophical foundation of the strategies and tactics of many leftists' organisations in South Africa and world-wide on how to dislodge the capitalist mode of production. Thus, from time to time the South African economic landscape is characterised by labour unrest and violent service delivery protests; because of the macro-economic trajectory of the government of the day. However, it must be noted that the ANC government economic policies in postapartheid South Africa cannot be packaged together into neo-liberalism. That is too simplistic and omits the complexity of the South African economic landscape. For instance, privatisation of services through tenders in government departments is an expression of neoliberalism. However, government still intervenes via regulation by deciding who must be awarded tenders. This is an anti-thesis of neo-liberalism. Hence, the central thesis of this article is that the South African government has a mixed-bag of economic policies epitomised by state interventionism and elements of neo-liberalism. The next section engages with literature review surrounding the theorisation of neo-liberalism.

\section{THE NEO-LIBERAL MODEL OF DEVELOPMENT}

The concept of neo-liberalism is like a buzz-word in South African body-politic. It is normally invoked in a pejorative sense to describe market-friendly policies. Partially, the historical roots of neo-liberalism can be traced in the classical work of Adam Smith (1776), entitled: The Wealth of Nations, which promotes economic competition, free trade and market freedom. More specifically, Smith (1776:572) speaks about the hidden hand of government in the economy; which he refers to as the invisible hand. This means that the government needs to take a back-seat in the economy. However, Smith (1776:194) encouraged government to intervene in the economy in order to protect the interests of the poor. All in all, his economic approach was capitalism with a 'human face' as opposed to rampant capitalism that is unregulated. On the contrary, Friedrich Hayek (1954:3-29) recommends the free-market capitalist system as having the ability to promote development, in particular amongst the poorest of the poor.
Writing from a liberal standpoint, Milton Friedman (1962:2) argues that the role of government needs to be limited in order to promote human freedom. He argues that the government needs to maintain law and order however this should protect private ownership of properties and encourage a healthy economic competition (1962:34). In this regard, the work of Adam Smith is taken to its logical conclusion by Milton Friedman by propagating the notion of market fundamentalism. This is in reference to the total deregulation of the economy. Milton Friedman argued from a neo-classical theoretical perspective that the free market system is the only 'beacon of hope' of development.

According to Klein (2007:57), the scholarly work of Milton Friedman is clearly a 'political bible' of neoliberalism. She argues that it advocated for lower taxes (in particular for capital), privatisation, fiscal discipline and less government intervention. Over and above that neo-liberalism rose to prominence as a political backlash against stagflation and government deficit. Lack of economic growth was seen as a failure of the Keynesianism in the 1970s. The weaknesses of the Keynesian economic system created a scope for the elevation of the capital above the state. Evidently, the neo-liberal model of development espouses the strong involvement of the market within the domain of the state. The neoliberals believe that only the market forces can bring about development in society. A strong state is regarded as a cause of lack of development in society precisely because it prevents economic growth from occurring. This view is held by proponents of neoliberalism.

Economist Joseph Stiglitz, in his book titled: Globalization and its discontents, state that there are two prominent politicians that have advocated for the spread of neo-liberalism across the globe. These individuals include Ronald Reagan (former President of the United States of America) and Margaret Thatcher (former Prime Minister of England), both embraced deregulation of the economy, privatization and fiscal discipline, etc (Stiglitz,2002:1). These ideologies were later on in history referred to as Reaganism and Thatcherism.

Social scientists seem to disagree around the conceptual analysis of neo-liberalism and the year in which it originated. The intellectual roots of neoliberalism can traced from post Second World War attempts to address reconstruction and development of a destroyed Europe and an economic framework to 
deal with independent colonial societies as a means to reduce the sphere of influence of the Soviet Union. In response, a range of developmental models were formulated to address this model, dependency theories, basic needs and so on. The capitalist economic framework was then redeveloped to deal with these criticisms and was relabelled neo-liberalism.

Neo-liberalism policies are those policies that are meant to attract investment with the assumption that there will be a trickle-down effect to the poor. Neoliberals hold a firm view that it is only the private sector that can bring about development in any country. It is worth noting that the trickling-down theory is at the heart of neo-liberalism. Stiglitz (2002:78) supports the above assertion when he argues that the proponents of neo-liberal hold a view that the trickle-down economics is driven by the 'Washington Censuses policies'.

Todaro and Smith (2003:812) echo the above sentiments when pointing out that the 'trick-down theory' is based on the idea that development is an economic activity which happens as result of gains of economic growth such as Gross Domestic Product (GDP) would address poverty through the creation of jobs and enhances economic opportunities. They go on to say that neo-liberals hold a strong view that growing the economy will eventually reduce unemployment and distribute wealth in society. They conclude by arguing that for neo-liberal first grow the economy and secondly address poverty and unemployment. Neoliberalism is a model for development it has goals for economic development and poverty eradication.

The neo-liberal model of development is normally associated with globalization. There is a certain symbiosis between neo-liberalism and globalization (Galbraith, 1996:14-20). According to Willis (2005:35), the requirements for neo-liberalism include among other things, the removal of state barriers to free trade such as quotas and tariffs, which of course also encourage the process of globalization. Economic globalization includes multinational corporations such as Coca-Cola, Toyota, BMW, McDonald's and Pepsi etc, operating on a world-wide basis. The free movement of goods around the globe is also central to the neoliberal tradition (Breakfast, 2013:38-46).

Proponents of the neo-liberal school of thought argue that economic growth through the free market system leads to economic as well as social development, for example poverty relief in society. They believe that this can only happen when there is privatization, removal of tariffs, policies in trade bilateral agreements, welcoming of foreign investors from First World Countries and a relaxation of labour laws. Supporters of neo-liberal ideas hold a view that 'big government' or a large public sector with heavy state regulation is not the best practice for economic growth and the creation of jobs; because investors are normally not keen to invest in a country that has heavy state regulation. Their line of argument is that investors do not make enough profit in a state regulated economy as opposed to in the free market system. For neo-liberals economic prosperity comes through the unimpeded operation of market forces. Neo-liberalism as policies advocated by multilateral institutions such as International Monetary Fund (IMF) and World Bank suggest adherence to the free market system (Harvey, 2005:2).

Most countries in the world, especially Latin America were given a taste of neoliberal policies. In Chile this ideology was primarily based on privatization, deregulation of the economy, and reduction of government expenditure, despite fiscal discipline being rejected by the majority of the citizens because the reduction of government expenditure led to essential services such as education, health and water service, to cite a few, being cut off (Klein, 2007:9). John Saul $(2005: 190-194)$ states that another country that was an experiment of neo-liberals was New Zealand. $\mathrm{He}$ argues that in New Zealand these neoliberal policies led to a 'financial crisis', inflation was high and poverty was increasing 'in a middle-class country'

It must be noted that some countries, especially the United States of America (under Ronald Reagan) and England (Thatcher Government) reduced their government expenditure on social development while on the other hand increasing their expenditure on military activities. This contradictory practice signifies that sometimes proponents of neo-liberalism pretend to be supporting the idea of reduction of government expenditure; however when it suits them they do the exact opposite (King, 1987:148-153). This is an epitome of the complexity of the neo-liberal ideology. Moreover, this exemplifies some of the contradictions neo-liberal and neo-classical economics.

Neo-liberalism is the mainstream model of development within development theory and practice. However, it must be noted that a number of scholars and political leaders have been asking for alternative models of development; because of the contradictions and the complexities of neo-liberalism. Ben Fine 
(1998:1-5) asserts that according to a call made in 1998 by Joseph Stiglitz, a former senior neo-classical economist at the World Bank, acknowledged that the 'Washington Consensus policies' failed to promote development for the majority; and proposed what is known as a 'post-Washington Consensus'. This means that capital needs to work side by side with the state in order to change society for the better for the majority of people (Fine, 1998:1-5). The next section examines the complexities of neo-liberalism in South Africa.

\section{THE APPLICATION OF NEO-LIBERALISM AND ITS CONTRADICTIONS IN SOUTH AFRICA}

Among other things, this section focuses on the reasons that caused the new democratic government in post-1994 to succumb to a neo-liberal world order (though business-friendly policies existed during apartheid) subsequent to the fall of the Soviet Union. It must be borne in mind that there were a lot of discussions about what the new socio-political setup would be in the new South Africa. Thus it is of paramount importance to provide a context when discussing neo-liberalism in a democratic South Africa. This view is supported by Neville Alexander (2002:150) when he argues that the application of neo-liberalism in the new South African should be understood in context, which includes the political transition towards democracy and the end of the apartheid system. However, neo-liberalism in South Africa as indicated before in this article has always been part of the South African political economy, contrary to the populism that market-friendly policies have been introduced only in post-apartheid South Africa. According to Sampie Terreblanche (2018:60), during the late 1980s the Mineral Energy Complex in South Africa succeeded in persuading the National Party government to accept neo-liberal economic policies which encouraged privatization.

In the mid-1980s, South Africa was engulfed by social protests through the length and the breath of the country. The violence broke-out mainly in black townships urban spaces in opposition to the brutality of the apartheid Nationalist government. The neo-liberal paradigm was consolidating its strength in many parts of the world via the structural adjustment programs mainly in the so-called developing countries. Consequently, this led to some political informal negotiations behind the scenes between ANC leaders, business leaders, academics and other civil society groups. The rationale behind these meetings was to map-out a strategy for the future of South Africa. More specifically, the Institute for a Democratic Alternative in South Africa (IDASA) organized the Dakar meeting in Senegal, in1987. This was after the 1985 meeting in the United Kingdom (Bradshaw, 2008:153, Van Zyl Slabbert, 2006:43, Du Preez, 2004:157-167).

The Dakar meeting was a precursor for democratization in the early 1990s. The business community had been assured by the ANC that it will not pursue socialism after it has ascended to the helm of power. The release of Nelson Mandela from Robben Island sparked hope in many people, both blacks and whites, for a new South Africa. The political move made by the African National Congress was to abandon the armed struggle. This move was welcomed by white South Africans as a gesture of political transition towards a new South Africa. However, within certain quarters of the ANC it was rejected as a betrayal of the struggle. Political negotiations in South Africa were meant for conflict management (Bradshaw, 2008:153).

The multi-party negotiations known as Convention for a Democratic South Africa (CODESA) lasted for three years (till late 1993) with the liberal constitution which guaranteed property rights and planned for a Government of National Unity (GNU) and 'powersharing' (Marais, 1998:90-91). The Azanian People's Organization (AZAPO) is the only liberation movement in South Africa that refused to participate in those multiparty negotiations during the early 1990s. They regarded the political transition as a sell-out process meant to benefit capitalists at the expense of workingclass. The Pan Africanist Congress (PAC) proposed that there should be an objective international observer to facilitate the multi-party negotiations. Their point was never taken into account, instead the deliberations went on.

The bone of contention surrounding the interim constitution was guaranteed property rights. This meant that there was no threat of nationalization of private institutions and therefore secured all the private property of capitalists. Bond (2006-16) contends that nationalists within the ANC sold-out during the multiparty negotiations by embracing neoliberalism. He goes on to say that these negotiations should be characterized as an 'elite transition'. He concludes by arguing that '... not only were free enterprise and property rights enshrined in every major economic policy statement and the constitution itself, full-blown neo-liberal compradorism became the dominant (if not universal) phenomenon within the ANC policy-making elite' 
This was a total betrayal of the Freedom Charter which has been a policy-guideline of the African National Congress since 1955. This is a socialist document which protects the rights of the poorest of the poor. According to the Freedom Charter (1955:3), the people shall share in the country's wealth. The national wealth of our country, the heritage of South Africans, shall be restored to all the people. The mineral wealth beneath the soil, the Banks and monopoly industry shall be transferred to the ownership of the people as a whole; all other industry and trade shall be controlled to assist the well-being of the people...

This quote re-affirms the earlier assertion that the content of the Freedom Charter is Marxist orientated. It embraces nationalization of mines and industries. This means that the means of production will be in the hands of the working-class. It is clear that during CODESA, ANC participants never took the Freedom Charter into account at all. Instead, they succumbed to the political economic pressure of marketfundamentalism. Another important aspect of the multiparty deliberations was the notion of a 'sunset clause'. The 'sunset clause' was developed by Joe Slovo, who held an opinion that National Party members in state institutions would undermine any settlement that did not address the interests of white people. The sunset clause was meant to keep white officials within the state machinery (Chazan et al., 1999:481).

The rank and file of the party was not part of these meetings, held behind closed doors. The interim government in 1993 asked for a loan from the IMF and World Bank. The 'Washington Consensus reflected just how much rigidly homogeneous power emanated from a few institutions and ideologues in the US capital city' (Bond, 2006:156). The United States of America encouraged the new transitional government to borrow money from the International Monetary Fund and World Bank. South Africa had, since 1951, made many loans under the apartheid regime (Turok, 2008:56-57). Again, this indicates that neo-liberalism in South Africa has always been at play even before the rise of the ANC to power in 1994, contrary to the view that neo-liberal policies have ushered in since 1996.

Marais (2008:122) reminds us that the ANC did not have a macro-economic policy subsequent to its unbanning in the early 1990s. The Macro-Economic Research Group (MERG) was established with an aim of crafting a macro-economic policy for South Africa. By and large, the MERG had a majority of leftists and advocated for a pro-poor model of development. The first policy document produced by the MERG was titled: 'Making Democracy Work'. It was underpinned by the tenets of Keynesianism (Siwisa, 2006:81-82).

South Africa's political transition was meant to necessitate economic growth and with the assumption that subsequently the majority would benefit (MacroEconomic Research Group 1993:1). Nonetheless, the policy document of the MERG was abandoned by the ruling party. Gevisser makes an interesting point when arguing that the ANC was much divided around the economic policy of the party in the early 90s. The economic policy formulated by the MERG was eventually not accepted as a party position due to a 'lack of consensuses. Trevor Manuel rejected this economic policy with the words: 'this is not ANC policy' (Manuel cited in Gevisser, 2007:669).

Yet contrary to Manuel's opinion, the MERG was an initiative of the ANC (Turok, 2008: 87). International financial institutions such as the International Monetary Fund and World Bank were discontented about the policy recommendations made by the MERG. More specifically, the MERG suggested an expansionary fiscal policy and the creation of a large bureaucracy in order to enable the state to be strong in its interventionist approach.

In the build-up to the elections of 1994, the ANC adopted the Reconstruction and Development Program (RDP) as an election manifesto. The RDP was a brainchild of Congress of South African Trade Unions (COSATU). By and large, the document in question was also embraced by civil society in SA. According to the RDP White Paper (1994:42), the RDP is meant to create employment in the formal economy and eliminate uneven development in the new South Africa. The South African economy was experiencing some problems in the mid-1990s, namely: a slow pace of economic growth, a low business confidence and had a huge apartheid debt. Nokaneng and Harmse (2009:41) point out that the South African economy grew slower than $2.5 \%$ in the early 1990's. This economic performance provided a justification for the ushering in of a neo-liberal policy called Growth, Employment and Redistribution (GEAR) which promoted a pro-market set of mechanisms, into place, in combination with certain redistributionist reforms.

Pottinger (2008:76) argues that GEAR was a shift from the Keynesian model of development to a market fundamentalism approach. He goes on to outline the macro-economic aims of GEAR as including: 
- $\quad$ The prediction that the economy would grow by 6 percent in 2000

- $\quad$ Privatization to create about 400000 jobs for the unemployed

- $\quad$ A fiscal deficit at 3 per cent

- $\quad$ Stability of the currency (the foreign exchange rate at the time was $R 4,5$ to the US dollar)'

- Inflation targeting.

Patrick Bond (2005:51) provides evidence around the policy targets of GEAR, he asserts that economic growth in 1996 was more than 10 percent lower than what GEAR predicted and fixed investment nearly 20 percent lower. The real value of the rand fell by 16 percent in 1996, far worse than the 8.5 percent decline predicted in GEAR at mid-year. The Reserve Bank's main interest rate was pushed up by 2 percent during 1996, reaching 17 percent by year-end, leaving an average real (after-inflation) rate of interest far higher than GEAR's prediction. Worst of all, 71000 jobs were lost in 1996, a far cry from the 126, 000 new jobs predicted in June that year. Bitter complaints from government's progressive social partners were heard, but neither Erwin nor other ANC leaders gave official recognition of the damage being done by the downshifting of macro-economic performance.

The evidence mentioned above shows that GEAR failed to achieve its policy intentions. Among other things these include job creation, economic growth by 6 percent a year and distribution of wealth in South Africa; especially to the historically disadvantaged population. Furthermore this means that a policy review surrounding GEAR is necessary. Any public policy that cannot achieve its initial aims signifies failure. For instance, South Africa's unemployment rate, while at $19 \%$ in 1996 , rose to $30 \%$ in 2002 , though it has eased slightly since then (UNDP, 2012:5). Hence the article among other things argues that that GEAR as a macroeconomic policy failed to reduce the gap between rich and poor.

The ruling party was committed to pay the apartheid debt and its interests. Among other things, GEAR was aimed at for the reduction of government expenditure (Growth, Employment and Redistribution, 1997:8-16). It is noteworthy that GEAR is largely a market-friendly inspired neo-liberal macro-economic policy which supports privatization, fiscal discipline, flexible labour laws through deregulation of the business and trade liberalization (removal of tariffs from imports coming into the country) and public-private partnerships (Breakfast, 2015:764). However, the magnitude and the role of the South African state, are definitely not neo-liberal in nature. Neo-liberalism (unregulated markets) with BBBEE requirements of state interventionism is also not neo-liberalism. Neoliberalism with highly-protected labour laws is not neoliberalism, as is the case in South Africa. These set of economic policies are fundamentally a smokescreen for institutionalisation of corruption, and a spoils system of political and business elite accumulation.

As such, this represents greater government regulation, not less, and cannot be unproblematically equated with neoliberalism, though they may be heavily influenced by it. They are market-friendly economic policies intended to maximise profit and individual acquisition of wealth, but they have been applied together with some distinctly different policies in respect of racial preferences, and very strong labour laws. In their own right the regulatory aspects of BBBEE, lend themselves to create a scope for corruption and accumulation by the new elite. The political and economic elite aligned to the ruling party have used both social and political capital in pursuit of personal accumulation.

The ANC government of late has adopted state led policies such as the 'New Growth Path' and the National Development Plan which espouse the notion of a development state as opposed to the populist view that South Africa is just simply a neo-liberal state. However, issues such as outsourcing or privatization of services and Public-Private Partnerships and much political rhetoric are neo-liberal. This also indicates the gaps in the discourse around the application of neoliberalism in South Africa.

According to Ferguson (2010:171), countries like South Africa, India, Brazil (just to cite a few) have increased their social spending while having some aspects of neo-liberalism in their macro-economic policies. He goes on to say that neo-liberalism is more complex than it might appear at face value. In South Africa, the ANC government has rolled out social grants since 1994 for the poorest of the poor simultaneously retaining key features of neo-liberalism such as privatisation of services (Ferguson, 2010:175178).

\section{CONCLUSION}

On the whole, models of development across the globe have always been characterised by 
contradictions and nuances as opposed to be inspired by a single ideology. This signifies a complexity in the concept of development. The characterisation of the left in South Africa that government policies are purely neo-liberal in nature is tantamount to political posturing. It is widely accepted uncritically both in the domain of social sciences and public discourse that the application of neo-liberalism is South Africa has occurred in a post-apartheid social order as a result of the introduction of GEAR policy. Though GEAR as a macro-economic policy was an expression of neoliberalism however market fundamentalism has always been embedded in the structure of the economy of South Africa. For instance, in the late 1980s the apartheid government privatized key state institutions, namely: Transnet, a small scale privatization of Iscor and Safmarine. Against this background, this article examines the weaknesses of the debate on the application of neoliberalism in South Africa. Neoliberalism is not only imposed by multi-lateral institutions such as the International Monetary Fund and the World Bank via the structural adjustment programs. Nonetheless, neo-liberalism is also created by local political and business elites at local government level through privatization of services.

Most importantly, there is a strong view among the left in South Africa that the African National Congress (ANC) is pursuing a neo-liberal agenda. On the contrary, the expansion of the size and the role of the South African state, are not inspired by neo-liberalism. The ANC government of in 2010 adopted a state led policy such as the 'New Growth Path' which supports the idea of a development state as opposed to the populist view that South Africa is just simply implementing business-friendly policies. Moreover, the National Development Plan (2011:38) supports the notion of creating a capable South African state. This is an anti thesis of neo-liberalism, precisely because it is a state led approach which is in line with the conception of having a developmental state in future in South Africa. However, this does not mean that there are no business-friendly policies in South Africa, such as outsourcing of services, Broad-Based Black Economic Empowerment (BBBEE), (though it also has an element of state interventionism by regulating the workings of the market-forces). This implies that neoliberalism as a model of development is not simplistic and straight forward. This also indicates the gaps in the discourse with regard to the implementation of neoliberalism in South Africa. This article contributes to the South African political economy debate by arguing that neo-liberalism has contradictions and complexities; it is not simplistic and straightforward.

\section{REFERENCES}

Alexander, N. 2002. An Ordinary Country: Issues in the Transition from Apartheid to Democracy in South Africa. Pietermaritzburg: University of Natal Press.

Bond, P. 2006. Elite transition: From apartheid to neo-liberalism in South Africa. Pietermaritzburg: University of Natal Press.

Bradshaw, G. 2008. Conflict management for South African students: Theory and application. Cape Town: New Voices Publishing.

Breakfast, N.B. 2013. Market Triumphalism and the South Africa State: A Case Study of Local Government in the Eastern Cape. Unpublished PhD thesis. Nelson Mandela Metropolitan University.

Breakfast, N. 2014. Anti-Neo-liberal Social Movements within the context of South African Municipalities. Administratio Publica. $22(1)$.

Breakfast, N. 2015. The Effect of Macro-Economic Policies on Sustainable Development in South Africa: 1994-2014. Journal of Public Administration. 55 (4).

Byrne, D. 1998. Complexity Theory and the Social Sciences: An introduction. London: Routledge.

Chazan, N, Lewis, P, Mortimer, R, Rothchild, D and Stedman, S. 1999. Politics and Society in Contemporary Africa. Third Edition. Colorado: Lynne Rienner Publishers. https://doi.org/10.1007/978-1-349-14490-7

Du Preez, M. 2004. Pale native: Memories of a renegade reporter Cape Town: Zebra Press.

Ferguson, J. 2010. The Use of Neo-liberalism. Antipode. 41 (1).

Fine, B. 1998. The developmental state is dead-long live social capital? Development and Change, 30(1):1-9. https://doi.org/10.1111/1467-7660.00105

Fine, B. \& Rustomjee, Z. 1996. The political economy of South Africa: From minerals-energy complex to industrialisation. London: Hurst and Company.

Freedom Charter, African National Congress. 1955. Adopted at the Congress of the People, 26 June 1945. Kliptown: South Africa.

Friedman, M. 1962. Capitalism and Freedom. Chicago: University of Chicago Press.

Gevisser, M. 2007. The Dream Deferred: Thabo Mbeki. Cape Town: Jonathan Ball Publishers.

Harvey, D. 2005. A Brief History of Neoliberalism. Oxford: Oxford University Press.

Hayek, F.A. 1954. Capitalism and Historians. London: Routledge and Kegan Paul Ltd.

Hibell, M. 2008. 'Development with Neo-liberal Policy: Is Income Inequality a Negative Societal Outcome'. Lunds University.

Galbraith, J.K. 1996. The Good Society: The Humane Agenda. New York: Houghton Mifflin Company.

Growth, Employment and Redistribution Document. 2004. The South African Government. The department of Finance: Pretoria.

King, D.S. 1987. The New Right: Politics, Markets and Citizenship. Chicago: The Dorsey Press. https://doi.org/10.1007/978-1-349-18864-2

Klein, N. 2007. The Shock Doctrine: The Rise of Disaster Capitalism. London: Penguin Books Ltd.

Lenin, V. 1901. 'What is to be Done'? London: Bookmarks.

Lenin, V. 1916. 'Imperialism, the Highest Stage of Capitalism.' London: Bookmarks.

Luxemburg, R. 2010. Socialism or Barbarism: Selected Writings. Edited by Le Blanc and Scott, H. London: Pluto Press. 
Macro-Economic Research Group. 1993. Making Democracy Work: A Framework for MacroEconomic Policy in South Africa. A Report to the Democratic Movement of South Africa. Centre of Development Studies South Africa.

Marias, H. 2011. South Africa Pushed to the Limit: The Political Economic of Change. Cape Town: University of Cape Town Press.

Marais, H. 2008. South Africa limits to change the political economy of transition. Revised and Expanded New Edition. Cape Town: University of Cape Town Press.

Marais, H. 1998. South Africa Limits to Change the Political Economy of Transition. Cape Town: University of Cape Town Press.

Marx, K. 1867 [1995]. Das Capital, Volume 1. Edited by McLellan, D. New York: Oxford University Press.

Marx, K and Engles, F. [1848] 1967. The Communist Manifesto. London: Penguin Books.

Mills, W, C. 1959. The Power Elite. New Edition. New York: Oxford University Press.

National Planning Commission. 2012. The National Development Plan: Vision for 2030. The South African Government. Department of Presidency: Pretoria.

Nokaneng, L and Harmse, C. 2009. 'Economic Policy: Some Lessons from Southeast Asia.' In Parsons, R. 2009. Zumanomics: Which Way to Shared Prosperity in South Africa? Challenges for a New South Africa. Johannesburg: Jacana Media (Pty).

Pottinger, B. 2008. The Mbeki Legacy. Cape Town: Zebra press.
Reconstruction Development and Program. 1994. RDP White Paper: discussion document: September 1994. www.anc.org.za/ ancdoc/policy. (Accessed on 16 November 2005).

Sampie, T. 2018. Lost in Transformation: South Africa's Search For a New Future since 1986. Johannesburg: KMM Review Publishing Company.

Smith, A. 1776 [2003]. The Wealth of Nations. London: David Campbell Publishers Ltd.

Saul, J. 2005. The Collapse of Globalism and the Reinvention of the World. London: Grove Atlantic Ltd.

Siwisa, B. 2006. The Development and Contentions Politics of the new Anti-Neo-liberal Social Movement in Post-Apartheid South Africa. Unpublished D.Phil Thesis. Oxford University.

Stiglitz, J. 2002. Globalization and its Discontents. London: Clays Ltd.

Turok, B. 2008. From the Freedom Charter to Polokwane: The Evolution of ANC Economic Policy. Cape Town: Picasso Headline.

United Nations Development Program. 2012. 'International Human Development IndicatorsUnited Nations Development Programme'. hdrstats.undp.org/en/countries/profiles (accessed on 2 May).

Van Zyl Slabbert, F. 2006. The other side of history: An anecdotal reflection on political transition in South Africa. Cape Town: Jonathan Ball Publishers.

Willis, K. 2005. Theories and Practical of Development: Routledge Perspective on Development. London. Routledge Taylor and Francis Group.

Received on 20-11-2019

Published on 31-12-2019

DOI: https://doi.org/10.6000/1929-7092.2019.08.139

(c) 2019 N.B. Breakfast; Licensee Lifescience Global.

This is an open access article licensed under the terms of the Creative Commons Attribution Non-Commercial License (http://creativecommons.org/licenses/by-nc/3.0/) which permits unrestricted, non-commercial use, distribution and reproduction in any medium, provided the work is properly cited. 